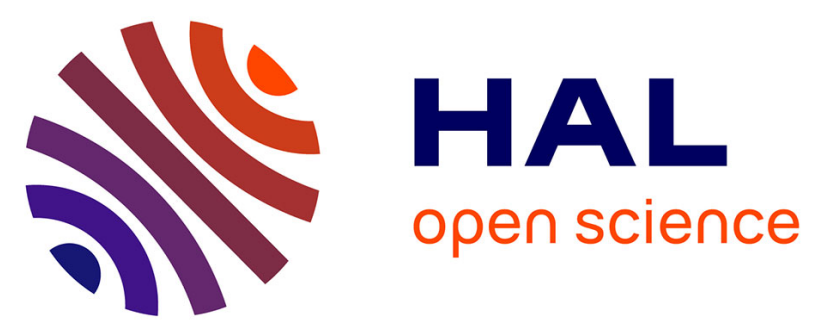

\title{
Contribution of water and cooked rice to an estimation of the dietary intake of inorganic arsenic in a rural village of West Bengal, India
}

\author{
Antonio J Signes, Kasturi Mitra, Francisco M. Burló, Angel A
}

Carbonell-Barrachina

\section{To cite this version:}

Antonio J Signes, Kasturi Mitra, Francisco M. Burló, Angel A Carbonell-Barrachina. Contribution of water and cooked rice to an estimation of the dietary intake of inorganic arsenic in a rural village of West Bengal, India. Food Additives and Contaminants, 2007, 25 (01), pp.41-50. 10.1080/02652030701385233 . hal-00577460

\author{
HAL Id: hal-00577460 \\ https://hal.science/hal-00577460
}

Submitted on 17 Mar 2011

HAL is a multi-disciplinary open access archive for the deposit and dissemination of scientific research documents, whether they are published or not. The documents may come from teaching and research institutions in France or abroad, or from public or private research centers.
L'archive ouverte pluridisciplinaire $\mathbf{H A L}$, est destinée au dépôt et à la diffusion de documents scientifiques de niveau recherche, publiés ou non, émanant des établissements d'enseignement et de recherche français ou étrangers, des laboratoires publics ou privés. 


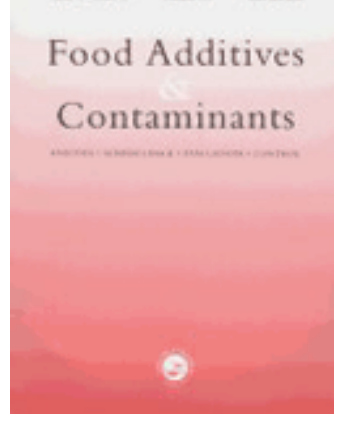

\section{Contribution of water and cooked rice to an estimation of the dietary intake of inorganic arsenic in a rural village of West Bengal, India}

\begin{tabular}{|r|l|}
\hline Journal: & Food Additives and Contaminants \\
\hline Manuscript ID: & TFAC-2006-364.R1 \\
\hline Manuscript Type: & Original Research Paper \\
\hline Author: & 04-Apr-2007 \\
\hline Complete List of Authors: & $\begin{array}{l}\text { Signes, Antonio; Universidad Miguel Hernández, Agro-Food } \\
\text { Technology } \\
\text { Mitra, Kasturi; Ramakrishna Vivekanda Mission, Institute of } \\
\text { Advanced Studies } \\
\text { Burló, Francisco; Universidad Miguel Hernández, Agro-Food } \\
\text { Technology } \\
\text { Carbonell-Barrachina, Angel; Universidad Miguel Hernández, Agro- } \\
\text { Food Technology }\end{array}$ \\
\hline Methods/Techniques: & $\begin{array}{l}\text { FAAS, Market basket survey, Metals analysis - AAS, Risk } \\
\text { assessment }\end{array}$ \\
\hline Additives/Contaminants: & $\begin{array}{l}\text { Environmental contaminants, Environmental contaminants - Soils, } \\
\text { Heavy metals - arsenic }\end{array}$ \\
\hline Food Types: & Cooked foods, Rice \\
\hline & \\
\hline
\end{tabular}

\section{SCHOLARONE \\ Manuscripts}


1 Contribution of water and cooked rice to an estimation of

2 the dietary intake of inorganic arsenic in a rural village of

3 West Bengal, India

4

5

6 Arsenic contamination of rice plants by arsenic polluted irrigation groundwater 7 could result in high arsenic concentrations in cooked rice. The main objective of 8 this study was to estimate the total and inorganic arsenic intakes in a rural 9 population of West Bengal through both drinking water and cooked rice.

10 Simulated cooking of rice with different levels of arsenic species in the cooking 11 water was carried out. The presence of arsenic in the cooking water was provided 12 by four arsenic species (arsenite, arsenate, methylarsonate, or dimethylarsinate) 13 and at three total arsenic concentrations $\left(50,250\right.$, or $500 \mu \mathrm{g} \mathrm{L}^{-1}$ ). The results 14 showed that the arsenic concentration in cooked rice was always higher than that 15 in raw rice and ranged from 227 to $1642 \mu \mathrm{g} \mathrm{kg}^{-1}$. The cooking process did not 16 change the arsenic speciation in rice. Cooked rice contributed a mean of $41 \%$ to 17 the daily intake of inorganic arsenic. The daily inorganic arsenic intakes for water 18 plus rice were 229, 1024, and $2000 \mu$ day $^{-1}$ for initial arsenic concentrations in

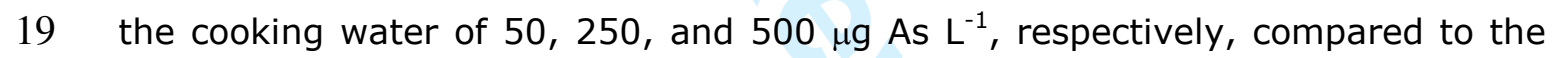
20 tolerable daily intake which is $150 \mu \mathrm{g} \mathrm{day}^{-1}$.

Key Words: arsenic speciation; cooked food; cooking water; organic arsenic; total arsenic. 
3 The world's two biggest cases of groundwater arsenic contamination and the 4 worst sufferings of people have been in Asia; in order of magnitude, these are 5 Bangladesh and West Bengal, India (Rahman et al. 2003). Several million people 6 in West Bengal consume water with arsenic concentrations which exceed by up 7 two orders of magnitude the threshold value of $10 \mu \mathrm{g} \mathrm{L}^{-1}$ recommended by the 8 WHO (Norra et al. 2005). Arsenic contamination of groundwater and illnesses of 9 people have been reported in nine districts out of a total of 18 districts in West 10 Bengal (Roychowdhury et al. 2003), including North-24-Parganas where this 11 study was located. Groundwater is the main source for drinking, cooking and 12 other household purposes in these arsenic-affected districts. Even the 13 agricultural system is mostly groundwater-dependent. In this way, a large 14 amount of arsenic deposits on the irrigated lands.

16 Recently, it has been considered that foods are responsible for an important part 17 of arsenic intake, and studies on total arsenic ( $t-A s$ ) in food obtained from 18 arsenic endemic areas have increased in recent years (Díaz et al. 2004; 19 Roychowdhury et al. 2003). Failure to consider the contribution of food intake of 20 arsenic could introduce a substantial bias into the estimation of risks for the 21 population of arsenic endemic areas (Díaz et al. 2004).

23 In most arsenic-contaminated areas of West Bengal, the residents depend 24 heavily on rice for their caloric intake (about $70 \%$ of total), suggesting that if 25 their rice is arsenic polluted it will become an important dietary source of this 26 metalloid (Watanabe et al. 2001). As rice is cultivated in arsenic contaminated 27 soils under anaerobic conditions (at which arsenic is highly available for plant 28 uptake), arsenic concentration in rice is high compared to other crops and 29 regions (Carbonell-Barrachina et al. 1998; Abedin et al. 2002; Meharg 2004).

31 Correct estimation of arsenic intake should consider not only the arsenic content 32 of the raw product but also the content of the contaminant in the product in the 33 form in which it is consumed by the population (raw or cooked). Studies have 34 shown changes in arsenic concentration after cooking of seafood (Devesa et al. 35 2001) and vegetables (She and Kheng 1992; Díaz et al. 1989). In arsenic 36 endemic areas, the high arsenic content in water used for cooking purposes is a 37 further source of contamination, mainly as inorganic arsenic. This is indicated by 
1 the high total arsenic contents found in the studies on total arsenic contents in

2 cooked foods from contaminated areas (Concha et al. 1998; Bae et al., 2002;

3 Roychowdhury et al. 2003; Sengupta et al. 2006). In many areas of West

4 Bengal, rice is washed and/or cooked with a substantial amount of water, which

5 is sometimes contaminated with arsenic. The actual amount of arsenic in cooked

6 rice could be either increased, by chelation of arsenic in water by binding on rice

7 grains, or decreased if water-soluble arsenic is released from rice into the water

8 to be discarded (Bae et al. 2002).

10 In the literature there are data for total arsenic contents in raw and cooked rice 11 (Roychowdhury et al. 2003; Islam et al. 2004; Norra et al. 2005), but few values 12 have been reported for inorganic arsenic (Ackerman et al. 2005; Laparra et al. 13 2005). However, knowledge of inorganic arsenic contents is essential for an 14 evaluation of health risks. Inorganic arsenic has been classified by the 15 International Agency for Research on Cancer (IARC) as a carcinogen to humans 16 (Díaz et al. 2004; Tsuda et al. 1992). Nevertheless, there are no prior references 17 to evaluate the influence of cooking on individual arsenic species in rice from 18 arsenic affected areas such as West Bengal. Up to our knowledge there are only 19 two studies dealing with speciation of arsenic in cooked rice, the first one carried 20 out by Laparra et al. (2005) using Spanish rice and the second one carried out

23 The aim of the present study was to determine total and inorganic arsenic 24 contents in cooked rice using arsenic polluted cooking water. Two factors were assayed in the cooking water: 1) arsenic speciation (arsenite, arsenate, methylarsonate, or dimethylarsinate) and 2) total arsenic concentration (50, 27250 , or $500 \mu \mathrm{g} \mathrm{L}^{-1}$ ). Besides, the contribution of cooked rice and drinking water 28 to the daily intake of total and inorganic arsenic of the inhabitants of an arsenicaffected rural village of West Bengal was evaluated.

\section{Materials and Methods}

\section{Instrumentation}

34 For arsenic speciation analysis, a high-performance liquid chromatography 35 (HPLC) system consisting of a Varian 9012 ternary pump (Varian, San Fernando, 36 CA, USA), a Rheodyne 7125 injector and a $50 \mu \mathrm{L}$ loop for sample introduction, 37 was used. Separations of arsenic species were performed on a Hamilton PRP X- 
1100 anion-exchange column $(10 \mu \mathrm{m}, 250 \mathrm{~mm} \times 4.1 \mathrm{~mm}$ i.d.; Hamilton, Reno, $2 \mathrm{NV}, \mathrm{USA})$. A guard column packed with the same material $(12-20 \mu \mathrm{m} ; 25 \mathrm{~mm} \times$ $3 \quad 2.3 \mathrm{~mm}$ i.d.) preceded the analytical column. Hydride generation of volatile 4 arsines prior to the detection was performed adding on-line solutions of $\mathrm{HCl}$ and $5 \mathrm{NaBH}_{4}$ by means of a Gilson Minipuls 3 peristaltic pump. The quantification of 6 arsenic was performed on a hydride generation system (PSA 10.044, PS 7 Analytical, Kent, U.K.) using an atomic fluorescence spectrometer system (AFS) 8 (PSA 10.044 Excalibur, PS Analytical) equipped with a boosted-discharge hollow 9 cathode lamp (Photron Pty. Ltd., Victoria, Australia). The analogical signal output 10 was connected to a computer equipped with chromatographic software (PS 11 Analytical).

13 Determination of total arsenic was performed with a Unicam Model Solaar 969 14 atomic absorption spectrometer equipped with a continuous hydride generator 15 Unicam Solaar VP90 (AAS-HG).

17 Other equipment used included a hot air oven (Selecta, Barcelona, Spain) with a 18 maximum temperature of $250{ }^{\circ} \mathrm{C}$, a grinder (Moulinex, Valencia, Spain), a 19 mechanical shaker Vibromatic (J.P. Selecta S.A., Barcelona, Spain), a centrifuge 20 (Heraeus BioFuge, Heraeus Instruments, Hanau, Germany), a sand bath (Falc, 21 Treviglio, Italy), model BS 70 with a maxim temperature of $200^{\circ} \mathrm{C}$, a muffle 22 furnace (Hobersal, Barcelona, Spain) and a lyophilizer (B. Biotech International, 23 Christ Alpha 2-4, Osterode, Germany).

\section{Reagents}

26 Deionized water $(18 \mathrm{M} \Omega \mathrm{cm}$ ) was used for the preparation of the reagents and 27 standards. All glassware was treated with $10 \% \mathrm{v} / \mathrm{v} \mathrm{HNO}_{3}$ for $24 \mathrm{~h}$ and then rinsed 28 three times with deionized water before use.

30 All chemicals were of, at least, pro analysis quality. Commercial standards of $31 \mathrm{NaAsO}_{2}$ (sodium meta-arsenite) and $\mathrm{Na}_{2} \mathrm{HAsO}_{4} \cdot 7 \mathrm{H}_{2} \mathrm{O}$ (sodium hydrogen arsenate) 32 were obtained from Panreac (Barcelona, Spain), while $\mathrm{CH}_{4} \mathrm{AsNaO}_{3} \cdot 1.5 \mathrm{H}_{2} \mathrm{O}$ 33 (monosodium methylarsonate sesquihydrate, $\mathrm{MA}$ ) and $\left(\mathrm{CH}_{3}\right)_{2} \mathrm{AsO}(\mathrm{ONa}) \cdot 3 \mathrm{H}_{2} \mathrm{O}$ 34 (monosodium dimethylarsinate trihydrate, DMA) were from Supelco (Bellefonte, 35 PA, U.S.A.) and Fluka (Buchs, Germany), respectively. Finally, anhydrous 36 trifluoroacetic acid (TFA) was from Sigma (St. Louis, MO, USA). 
1 Study Area

2 The study was conducted in a village of North 24-Parganas district, 3 approximately $25 \mathrm{~km}$ from Calcutta (India). The total area of the village is 5.0 $4 \mathrm{~km}^{2}$, with 22270 people living in residential area of the village with the 5 remaining area being cultivated land. The average annual income of the villagers 6 is 350 US $\$ a_{n n u m}^{-1}$. The main source of drinking water for the village is 100 , 7 mainly shallow, wells and tube wells, for drinking purposes. The village was 8 chosen as the model village in our study because it was known that $70 \%$ of its 9 tube wells had As concentrations above $0.05 \mathrm{mg} \mathrm{L}^{-1}$ and it is highly affected by

10 As contamination in the groundwater.

\section{Food questionnaire}

13 A $24 \mathrm{~h}$ dietary recall questionnaire was administered to homes in the studied 14 village in West Bengal. It asked for information about the type and quantity of 15 water and foods ingested the previous day, and how the foods were prepared for 16 their consumption, raw or cooked. The design of the questionnaire was carried 17 out by the Miguel Hernandez University (Spain) and approved by the 18 Ramakrishna Vivekananda Mission (West Bengal, India), a registered society 19 with a wide expertise in working with villagers in the studied area (Calcutta), and 20 it was administered by professionals from this society.

22 The number of interviewees was set at 115 (60 male and 55 female), with ages 23 above 12 years old to below 60 years. The interviewees selected were mainly 24 farmers and housewives who normally eat at home, buy or get their food from 25 local markets and/or farms, cook themselves and take drinking water from 26 surrounding tube wells. People working at nearby cities were not included in the 27 survey; they are not representative of endemic arsenic area because they eat 28 frequently at the city. 
$1 \quad$ Rice samples

2 Commercial rice samples were collected in farms surrounding the previously 3 cited rural village of the North 24-Parganas district. Rice samples from different 4 periods of the year and varieties were analyzed for total and inorganic arsenic 5 concentrations (Table I). As expected boro rices contained higher t-As and i-As 6 concentrations than aus and aman samples; these higher contents are related to 7 the use of higher volume of arsenic polluted groundwater for irrigation of the 8 boro rice plants (grown during summer time) compared to aus and aman plants. 9 After carefully study of information summarized in Table $\mathbf{I}$, authors decided to 10 select one of the boro varieties, the khitish rice (IET-4094), for their experiments 11 because boro rices are those representing the highest potential health risks for 12 humans.

14 Cooking conditions

15 Worldwide, there are three common methods of cooking rice (Sengupta et al. 16 2006): a) The traditional method still used by more than $90 \%$ of the villagers in 17 Bengal delta: raw rice is washed until the washings become clear (5-6 times), 18 washings are discarded and then the rice is boiled in excess water (5-6 times 19 the weight of raw rice) until cooked, finally discarding the remaining water 20 (discard water) by tilting the pan against the lid before serving the rice; $b$ ) the 21 rice is washed as in "a" and boiled with water of a volume 1.5-2 times the 22 weight of rice until no water is left to discard; c) unwashed rice is boiled with 23 water 1.5-2 times the weight of rice; the wash and discard steps are both 24 omitted. This is the contemporary method.

26 The first experiment was conducted to investigate effect of a) arsenic species and b) arsenic concentration on the arsenic content in the cooked rice. The rice was cooked using deionized water or deionized water spiked with different levels $\left(50,250\right.$ or $\left.500 \mu \mathrm{g} \mathrm{L}^{-1}\right)$ of only one of the following four arsenic species: arsenite, arsenate, methylarsonate (MA), or dimethylarsinate (DMA).

32 The food survey carried out in this study showed that none of the three methods 33 described above was the most popular in the studied rural village; the most 34 popular rice cooking method was in between methods "a" and "c" (it is a hybrid 35 in the evolution of method "a" towards method "c"). The unwashed rice is boiled 36 with a volume of water 1.5-4 times the weight of rice; the wash step is omitted. 
1 Thus, the rice $(250 \mathrm{~g})$ was added to boiling water $(750 \mathrm{~mL})$ and kept under this

2 heat conditions until cooked; the remaining water was discarded. No additional

3 ingredients were employed.

4

5 The second experiment was carried out to investigate the effect of arsenic

6 speciation in the cooking water on the arsenic speciation in the cooked rice. Rice

7 was cooked in the same way as described for the first experiment; cooking water

8 was spiked with four arsenic species (arsenite, arsenate, MA, or DMA) but only

9 one arsenic concentration was studied $250 \mu \mathrm{g} \mathrm{As} \mathrm{L^{-1 }}$.

11 Once cooked, all rice samples were frozen at $-20^{\circ} \mathrm{C}$ and then freeze-dried. The 12 lyophilized samples were ground in a domestic apparatus, and the resulting 13 powder was vacuum-packed and kept in the freezer at $-20{ }^{\circ} \mathrm{C}$ until analysis. 14 Total arsenic concentrations were measured in dry raw rice, wet cooked rice, 15 cooking water, and discarded starched water.

\section{Quantification of total arsenic}

18 A $0.250-g$ portion of lyophilized rice sample was weighed and digested using the 19 ashing method previously described by Muñoz et al. (2000). Calibration 20 standards were prepared using the same $\mathrm{HCl}$ concentration of the samples and 21 certified materials. The instrumental conditions used for arsenic determination by HG-AAS were as follows: reducing agent: $1.4 \%(\mathrm{~m} / \mathrm{v}) \mathrm{NaBH}_{4}$ in $0.4 \% \mathrm{NaOH}, 5$ $23 \mathrm{~mL} \mathrm{~min}{ }^{-1} ; \mathrm{HCl}$ solution: $10 \%(\mathrm{v} / \mathrm{v}), 10 \mathrm{~mL} \mathrm{~min}^{-1}$; carrier gas: argon, $250 \mathrm{~mL}$ $24 \mathrm{~min}^{-1}$ flow rate; and for atomic absorption spectrometry, wavelength: $193.7 \mathrm{~nm}$; spectral bandpass: $0.5 \mathrm{~nm}$; hollow cathode lamp current setting $8 \mathrm{~mA}$; air/acetylene flame with a fuel flow rate of $0.8 \mathrm{~L} \mathrm{~min}^{-1}$.

The certified reference materials (rice flour = NIST SRM 1568a, and bush, branches and leaves = GBW07603) used for testing this analytical method were provided by CYMIT Química, S.L. (Barcelona, Spain) and produced by the National Institute of Standards and Technology of U.S.A. and the Institute of

\section{Quantification of arsenic species}

35 The method used for the extraction of the arsenic species was that described by 36 Heitkemper et al. (2001). Dried and milled rice sample (0.5 g) was treated with $373 \mathrm{~mL}$ of $2 \mathrm{M}$ TFA. The mixture was allowed to stand for $6 \mathrm{~h}$ at $100{ }^{\circ} \mathrm{C}$ in a $60 \mathrm{~mL}$ 
1 capped HDPE centrifuge tube. The mixture was centrifuged and the supernatant 2 was collected and diluted to volume with deionized water. The TFA extracts were

3 filtered through a $045 \mu \mathrm{m}$ nylon syringe filter prior to analysis by HPLC-HG-AFS. 4

5 The arsenic species (arsenite, arsenate, MA, and DMA) were determined in the 6 water extract using HPLC-HG-AAS. Separation of the arsenic compounds was 7 carried out in ca. $15 \mathrm{~min}$ in the anion-exchange column, using a $25 \mathrm{mM}$ 8 phosphate buffer ( $\mathrm{pH} \mathrm{6.0)}$ as mobile phase at $1.1 \mathrm{~mL} \mathrm{~min}^{-1}$ flow rate. The elution 9 order was arsenite, DMA, MA, and arsenate.

$1150 \mu \mathrm{L}$ of sample were injected in the HPLC system, following the instrumental 12 and analytical conditions described in Table II. Under these conditions, the 13 retention times were $3.1,4.2,5.1$ and $8.6 \mathrm{~min}$ for arsenite, DMA, MA, and 14 arsenate, respectively. Figure 1 shows the separation obtained in: a) a $50 \mu \mathrm{g} \mathrm{L}^{-1}$ 15 standard of arsenite, DMA, MA, and arsenate, b) the certified material NIST SRM $161568 a$, rice flour, c) raw rice, and d) rice cooked using arsenite-polluted water. 17

18 External calibration was accomplished using standard concentrations of 1, 10, $1920,30,40$, and $50 \mu \mathrm{g} \mathrm{L}^{-1}$ of each of the four arsenic species studied (arsenite, 20 DMA, MA and arsenate).

22 Information on the certified material NIST SRM 1568a (rice flour) was used for 23 testing this analytical method.

\section{Statistical analyses}

26 All data were subjected to analysis of variance (ANOVA) and the Tukey least significant difference multi-comparison test to determine significant differences 28 among samples (arsenic species and/or arsenic concentration). The statistical analyses were done using SPSS 12.0 (SPSS Science, Chicago, USA).

\section{Results and discussion}

33 Analytical Quality Assurance

34 Total arsenic. The analytical characteristics for the total arsenic methodology 35 were as follows: detection limit, $7 \mu \mathrm{g} \mathrm{kg}^{-1}$; precision $2 \%$; accuracy for rice flour 36 (NIST SRM 1568a), found value $=0.29 \pm 0.04 \mathrm{mg} \mathrm{kg}^{-1}$ (certified value $=0.29 \pm$ 
$10.03 \mathrm{mg} \mathrm{kg}^{-1}$ ); accuracy for bush, branches and leaves (GBW07603), found value $2=1.18 \pm 0.03 \mathrm{mg} \mathrm{kg}^{-1}$ (certified value $=1.25 \pm 0.10 \mathrm{mg} \mathrm{kg}^{-1}$ ).

4 Arsenic speciation. An estimate of the instrumental detection limit (IDL) for 5 each of the four arsenic species was calculated based on 3 times the standard 6 deviation of peak area measurements for replicate $50 \mu \mathrm{L}$ injections of an arsenic 7 standard containing $2.0 \mu \mathrm{g} \mathrm{L}^{-1}$ each of arsenite, arsenate, MAA and DMA. The IDL 8 estimates were $1.7,1.5,1.1$, and $1.4 \mu \mathrm{g} \mathrm{L}^{-1}$, respectively. Finally, estimates of 9 the method detection limits (MDLs) were calculated using the IDLs multiplied by 10 a dilution factor of 10 ( $0.5 \mathrm{~g}$ of rice diluted to a final volume of $5 \mathrm{~mL}$ ). The MDLs 11 were $17,15,11$, and $14 \mu \mathrm{g} \mathrm{As} \mathrm{kg}^{-1}$ fresh matter for arsenite, DMA, MA and 12 arsenate, respectively. The average fortification recoveries (for a $0.75 \mu \mathrm{g} \mathrm{As}$ 13 spike on $10 \mathrm{~mL}$ of a $20 \mu \mathrm{g} \mathrm{L}^{-1}$ standard) through the method were $94 \%, 89 \%$, $1490 \%$, and $92 \%$ for arsenite, DMA, MA, and arsenate. No significant 15 reduction/oxidation reactions were observed in these fortification studies.

17 There are no food certified reference materials available for arsenic species 18 and/or inorganic arsenic. The quality criterion adopted for testing the current 19 analytical method, therefore, was the overlapping between the ranges of I-As 20 found in a certified rice flour sample (NIST SRM 1568a): $0.082 \pm 0.09 \mathrm{mg} \mathrm{kg}^{-1}$ 21 and those reported in a previous study carried out by Heitkemper et al. (2001), $220.083 \pm 0.06 \mathrm{mg} \mathrm{kg}^{-1}$ using the same method of extraction for the arsenic 23 species.

Finally, the total arsenic concentration (sum of the four studied arsenic species) of the NIST SRM 1568a, $0.268 \pm 0.028 \mathrm{mg} \mathrm{kg}^{-1}$, was compared with the certified value of the material, $0.290 \pm 0.030 \mathrm{mg} \mathrm{kg}^{-1}$, and shows the goodness of the analytical method used.

\section{$1^{\text {st }}$ Experiment "total arsenic in cooked rice"}

31 The ratio of added water to raw rice was 3:1 (750 mL: $250 \mathrm{~g})$, which is typical of 32 the cooking habits in West Bengal and Bangladesh (Misbahuddin 2003). 33 According to Bae et al. (2002) the water:rice ratio ranges from 3.2:1 to 4.0:1 in 34 Bangladesh, which was significantly higher than the ratio used, for example, in 35 Japan, 1.3:1. 
1 Tables III-IV show the effect of t-As concentration and As speciation initially 2 present in the cooking water on the t-As concentration in the cooked rice. In 3 general, no effect of t-As concentration (Table III) or As speciation (Table IV) 4 was found on the volumes of absorbed water in the cooked rice (absorbed water 5 was measured by drying cooked rice and raw rice at $70^{\circ} \mathrm{C}$ until constant weights 6 and subtracting these two water contents); although the rice cooked with 7 arsenite retained significantly more water $(639 \pm 17 \mathrm{~mL})$ than the others (mean 8 of $533 \pm 17 \mathrm{~mL})$.

10 As will be discussed later, results from our calculations suggest that cooked rice 11 could be an important source of As if it is boiled using As-contaminated water. 12 According to the experimental data, $1000 \mathrm{~g}$ of cooked rice will correspond to 13 roughly $309 \mathrm{~g}$ of raw rice, and about $691 \mathrm{~g}$ of contaminated water. Therefore, 14 this cooked rice will provide an additional and substantial burden of As to that 15 coming from the drinking water.

17 The amount of As in the cooked rice was 2.2-20.0\% higher than predicted (from 18 raw rice and absorbed water) for initial As concentrations of 250 and $500 \mu \mathrm{g}$ As $19 \mathrm{~L}^{-1}$, respectively. These results might suggest either that $A s$ in the water is 20 chelated by rice grains, or that As becomes concentrated during the cooking 21 process, because of evaporation.

23 Díaz et al. (2004) stated that the total arsenic contents in raw food can alter in 24 various ways during cooking treatments, with a consequent effect on the intake 25 of this contaminant. Cooking treatments such as boiling and frying can alter total 26 arsenic content by a) concentration of arsenic through loss of water, volatiles, 27 and, to a lesser extent, certain macronutrients (carbohydrates, lipids, and 28 proteins) and b) loss of As through solubilization.

30 On the other hand, when the initial As concentration was $50 \mu \mathrm{g} \mathrm{As} \mathrm{L}^{-1}$, the As 31 content in the cooked rice was about $30 \%$ lower than expected (Table III). 32 These experimental observations indicate that the concentration of As through 33 loss of water in the cooking process is not a good explanation. Besides, another 34 experimental parameter sustaining this statement is that the ratio of As in initial 35 water to that in the discarded water was close to 1 in samples cooked with water

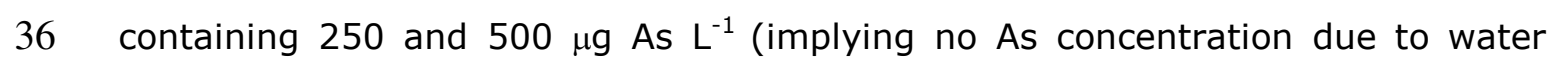

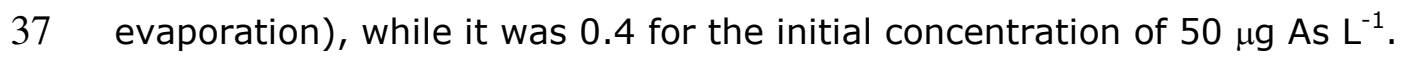


2 Data on Table IV shows a significantly higher As concentration in the rice 3 cooked using polluted cooking water containing arsenite. The mechanisms for 4 capturing $\mathrm{t}$-As and inorganic arsenic ( $\mathrm{i}$-As) might be related to the incorporation 5 of water into food during cooking. This statement is supported by the fact that 6 significantly more water was absorbed by the rice cooked with arsenite (639 \pm 17 $7 \mathrm{~mL}$ ) compared to the others (532 $\pm 11 \mathrm{~mL})$. The high water retention capacity of 8 the rice might be due to the high starch content in this cereal ( $\cong 90 \%$ ), which 9 incorporates a large quantity of water during its gelatinization in the boiling 10 process (Tinarelli 1989).

$122^{\text {nd }}$ Experiment "arsenic speciation in cooked rice"

13 Arsenic speciation of raw rice demonstrated that arsenic was mainly present as 14 inorganic forms, $206.8 \mu \mathrm{g}$ arsenite $\mathrm{kg}^{-1}$ rice plus $39.7 \mu \mathrm{g}$ arsenate $\mathrm{kg}^{-1}$, and 25.5 $15 \mu \mathrm{g} \mathrm{DMA} \mathrm{kg}{ }^{-1}$ were also found. Considering that $0.250 \mathrm{~kg}$ of raw rice were used in 16 our cooking simulations, the total amounts of $51.7 \mu \mathrm{g}$ arsenite, $9.9 \mu \mathrm{g}$ arsenate 17 and $6.4 \mu \mathrm{g}$ DMA were incorporated into the cooking system from the raw rice. 18 Besides, a total of $187.5 \mu \mathrm{g}$ of each species (arsenite, arsenate, MA, and DMA) 19 were incorporated from the spiked cooking water in each of the different 20 simulations. In summary, a total of $255.5 \mu \mathrm{g}$ arsenic was added to the cooking 21 system from both rice and spiked cooking water.

23 A control cooking experiment using arsenic-free water was carried out and 24 showed that cooking caused an oxidation of arsenite to arsenate, and a complete 25 transformation of the initial DMA into MA and inorganic arsenic. Arsenic was 26 present in this cooked rice as $110.4 \mu \mathrm{g}$ arsenate $\mathrm{kg}^{-1}, 76.4 \mu \mathrm{g}$ arsenite $\mathrm{kg}^{-1}$, and $27 \quad 10.8 \mu \mathrm{g} \mathrm{MA} \mathrm{kg}^{-1}$.

29 Data on Table $\mathbf{V}$ showed that when arsenic was present in the cooking water as 30 inorganic forms (arsenite or arsenate), it was mainly present in the cooked rice 31 as inorganic forms as well. However, about $10 \%$ of the final arsenic in the 32 cooked rice was present under the form of non-added species; for example, 33 when As was initially present in the cooking water as arsenite, $23.8 \pm 0.4 \mu \mathrm{g}$ of 34 arsenite were transformed in arsenate. On the other hand, if As was initially 35 present in the cooking water under organic forms (MA or DMA), no 36 transformation between organic species occurs; however, a significant amount of 37 arsenite was found. 
2 To date, the only previous reference found dealing with the contents of i-As in 3 cooked foods is the study carried out by Díaz et al. (2004) in Chile, with a 4 maximum concentration of $1.58 \mu \mathrm{g} \mathrm{g}^{-1} \mathrm{ww}$ in maize boiled in water containing $50.572 \mu \mathrm{g} \mathrm{As} \mathrm{mL}^{-1}$. The lack of data concerning i-As content in cooked samples 6 from arsenic endemic areas shows the novelty of the results reported in the 7 present work.

8

9 In general, from this section dealing with As speciation in the cooked rice it can

10 be concluded stating that arsenic will be present in the cooked rice in the same 11 form it was initially found in the cooking water and raw rice.

13 Estimation of arsenic intake and evaluation of risks

14 From the data provided by the $24 \mathrm{~h}$ recall questionnaire administered to the 15 inhabitants of the village in 24-North Parganas district [quantity of water $(\mathrm{mL})$, 16 rice ingested $(\mathrm{g})$ ] and the $\mathrm{t}$-As and $\mathrm{i}$-As concentrations spiked in the cooking 17 water and found in raw and/or cooked rice analyzed (Tables III and IV), the 18 intakes of $\mathrm{t}$-As and $\mathrm{i}$-As were calculated, and, expressed as $\mu \mathrm{g}$ As day ${ }^{-1}$, are 19 shown in Table VI. According to the food habits survey, the average daily water 20 intake for adult (mean of males and females) was $2.5 \mathrm{~L}$. This result is relatively 21 low compared to results provided by Roychowdhury et al. (2003), who found that 22 adult males, adult females and children ( $<10$ years of age) consumed 4,3 , and 2 $23 \mathrm{~L}$, respectively, at Murshidabad district, West Bengal. Besides, a mean rice intake 24 of about $450 \mathrm{~g}$ for adults was used for our calculations, while Roychowdhury et 25 al. (2003) found rice intakes of about $750 \mathrm{~g}$.

Our results proved that the general assumption that As is present in the drinking water and foods mainly under inorganic forms, arsenite and/or arsenate, is correct; the As intakes estimated in this study show that the daily i-As intake represents between 82 and $99 \%$ of the daily T-As intake. This is due to the types of foods analyzed, water and rice, as indicated earlier, i-As are the major 32 species.

34 Díaz et al. (2004) studied the contribution of water, bread, and vegetables to the 35 dietary intake of arsenic in a rural village of Northern Chile. They studied these 36 items in two different periods, in which the water used by the population for 37 drinking and cooking purposes contained 0.572 (first period) or $0.041 \mu \mathrm{g} \mathrm{m}^{-1}$ 
1 (second period). The foods studied contribute to $5 \%$ (first period) or $30 \%$

2 (second period) of the total As intake. Consequently, Díaz et al. (2004)

3 concluded that the significance of the intake of As from food increases as the

4 concentration of As in water decreases. This result should be taken into account

5 in non-arsenic endemic areas. The main difference between the study by Díaz et

6 al. (2004) and the present study carried out in West Bengal is the amount of rice

7 being consumed by the Indian population, $450 \mathrm{~g} \mathrm{day}^{-1}$. With these initial

8 considerations, only rice consumption will contribute $45.0 \%, 38.6 \%$, and 37.2

$9 \%$ to the final total As intake for cooking water containing 50, 250, and $500 \mu \mathrm{g} \mathrm{L}^{-}$

101 , respectively (Table VI).

12 Assuming a body weight of $70 \mathrm{~kg}$ for adult people in West Bengal, the reference

13 intakes stated by the $\mathrm{FAO} / \mathrm{WHO}$ are equivalent to $150 \mu \mathrm{g} \mathrm{i-As}$ day $^{-1}$ for adult 14 people (Díaz et al. 2004; WHO 1989).

16 In India, the studies carried out by Roychowdhury et al. (2002-2003) in West

17 Bengal also provide data for $t$-As intake from water and from raw and cooked

18 food. Assuming that at least $50 \%$ of the t-As in food sample is i-As, the

19 maximum intake obtained from water and foods was $708 \mu \mathrm{g} \mathrm{day}^{-1}$ in adult males,

20 which is 4.7 times greater than the TDI. In this case, the daily intake contributed

21 by foodstuffs (rice, vegetables, and spices) was $189 \mu \mathrm{g}, 27 \%$ of the daily t-As 22 intake.

24 In the present study, the daily arsenic intakes obtained from water plus rice were 227, 1018, and $1989 \mu \mathrm{g}$ As day ${ }^{-1}$ for initial As concentrations in the cooking

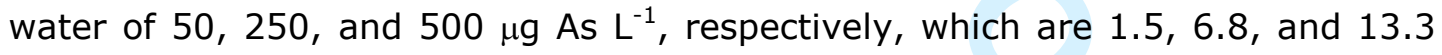
times greater than the TDI. Similar figures are obtained when inorganic species 28 are considered (Table VI); 229, 1024, and $2000 \mu \mathrm{g}$ As day ${ }^{-1}$ for initial As 29 concentrations in the cooking water of 50,250 , and $500 \mu \mathrm{g} \mathrm{As} \mathrm{L}^{-1}$, respectively, which are $1.5,6.8$, and 13.3 times greater than the TDI.

\section{Conclusions}

33 Our results suggest that rice cooked with arsenic-contaminated water might be

34 an important source of arsenic, especially inorganic arsenic, and that the 35 conditions of the cooking process (ratio rice:water and volume of water 36 discarded) could affect the amount of this element in final cooked rice. A dose37 response association between arsenic exposure and any health effects might 
1 underestimate the health risk of arsenic if the intake of this element from 2 sources other than drinking water is not included. Finally, if cooking water 3 containing low levels of arsenic can be provided to villagers, even if their 4 vegetables are still contaminated with arsenic, cooked items will have an arsenic 5 concentration lower than expected due to migration of some the arsenic to the 6 cooking water.

\section{Acknowledgements}

9 This paper has been produced with the financial assistance of the European Union 10 (Development of a low cost technology for in-situ treatment of groundwater for 11 potable and irrigation purposes, TIPOT, ASI/B7-301/2598/24-2004/79013), MEC 12 (CTM2005-2425-E), and Caja de Ahorros del Mediterráneo (CAM-2006). The 13 contents of this document are the sole responsibility of UMH and can under no 14 circumstances be regarded as reflecting the position of the European Union 15 and/or CAM.

\section{References}

18

Abedin MJ, Feldman J, Meharg AA. 2002. Uptake kinteics of arsenic species in rice plants. Plant Physiology 128:1120-1128.

Ackerman AH, Creed PA, Parks AN, Fricke MW, Schwegel CA, Creed JT, Heitkemper DT, Vela NP. 2005. Comparison of a chemical and enzymatic extraction of arsenic from rice and an assessment of the arsenic absorption from contaminated water by cooked rice. Environmental Science and Technology 39:5241-5246.

Bae M, Watanabe C, Inaoka T, Sekiyama M, Sudo N, Bokul MH, Ohtsuka R. 2002. Arsenic in cooked rice in Bangladesh. Lancet 360:1839-1840.

Carbonell-Barrachina AA, Aarabi MA, DeLaune RD, Gambrell RP, Patrick WH Jr. 1998. The influence of arsenic chemical form and concentration on Spartina patens and Spartina alterniflora growth and tissue arsenic concentration. Plant and Soil 198:33-43.

32 Concha G, Nermell B, Vahter M. 1998. Metabolism of inorganic arsenic in children with chronic high arsenic exposure in northern Argentina. Environmental Health Perspectives 106:355-359. 
Devesa $V$, Macho $M L$, Jalón $M$, Urieta I, Muñoz $O$, Súñer $M A$, López $F$, Vélez $D$, Montoro, R. 2001. Arsenic in cooked fish products: Study on the effect of cooking on total and inorganic contents. Journal of Agricultural and Food Chemistry 49:4132-4140.

Díaz OP, Leyton I, Muñoz O, Núñez N, Devesa V, Súñer MA, Vélez D, Montoro, R. 2004. Contribution of water, bread, and vegetables (raw and cooked) to dietary intake of inorganic arsenic in a rural village of Northern Chile. Journal of Agricultural and Food Chemistry 52:1773-1779.

Díaz O, Recabarren E, Piñeiro M. 1989. Contents in raw potato, cooked potato and industrialized products as mashed potatoes. Reviews in Clinical Nutrition 17:116-121.

Heitkemper DT, Vela NP, Stewart KR, Westphal CS. 2001. Determination of total and speciated arsenic in rice by ion chromatography and inductively coupled plasma mass spectrometry. Journal of Analytical Atomic Spectrometry 16:299-306.

Islam MR, Islam S, Jahiruddin M, Islam MA. 2004. Effects of irrigation water arsenic in the rice-rice cropping system. Journal of Biological Sciences. $4(4): 542-546$.

Laparra JM, Vélez D, Barberá R, Farré R, Montoro R. 2005. Bioavailability of inorganic arsenic in cooked rice: Practical aspects for human health risk assessments. Journal of Agricultural and Food Chemistry 53:8829-8833.

Meharg AA. 2004. Arsenic in rice. Understanding a new disaster for South-East Asia. Trends in Plant Sciences 9:415-417.

Misbahuddin M. 2003. Consumption of arsenic through cooked rice. Lancet 361:435-436.

Muñoz O, Devesa V, Suñer MA, Vélez D, Montoro R, Urieta I, Macho ML, Jalón M. 2000. Total and inorganic arsenic in fresh and processed fish products. Journal of Agricultural and Food Chemistry 48:4369-4376.

Norra S, Berner ZA, Agarwala P, Wagner F, Chandrasekharam D, Stüben D. 2005. Impact of irrigation with As rich groundwater on soil and crops: A geochemical case study in West Bengal Delta Plain, India. Applied Geochemistry. 20:1890-1906.

Rahman MM, Mandal BK, Chowdhury TR, Sengupta MK, Chowdhury UK, Lodh D, Chanda CR, Basu GK, Mukherjee, Saha KC, Chakraborti D. 2003. Arsenic groundwater contamination and sufferings of people in North 24-Parganas, one of the nine arsenic affected districts of West Bengal, India. Journal of Environmental Science and Health A 38:25-59. 
1 Roychowdhury T, Tokunaga $H$, Ando M. 2003. Survey of arsenic and other heavy metals in food composites and drinking water and estimation of dietary intake by the villagers from an arsenic-affected area of West Bengal, India. Science of the Total Environment 308:15-35.

5 Roychowdhury T, Uchino T, Tokunaga H, Ando M. 2002. Survey of arsenic in food composites from an arsenic-affected area of West Bengal, India. Food Chemical Toxicology 40:1611-1621.

8 Sengupta MK, Hossain MA, Mukherjee A, Ahamed S, Das B, Nayak B, Chakraborti 9 D. 2006. Arsenic burden of cooked rice: Traditional and modern methods. Food and Chemical Toxicology. 44:1823-2829.

11 She LK, Kheng LC. 1992. Arsenic contents in some Malaysian vegetables. Pertanika 15:171-173.

13 Tinarelli A. 1989. El Arroz. Madrid (Spain): Ediciones Mundi-Prensa.

14 Tsuda T, Babazono A, Ogawa T, Hamad H, Mino Y, Aoyama H, Kuramatani T, 15 Hotta N, Harada M, Inomata S. 1992. Inorganic arsenic: A dangerous enigma for mankind. Applied Organometallic Chemistry 6:309-322.

Watanabe C, Inaoka T, Kadono T, Nagano M, Nakamura S, Ushijima K,

WHO. 1989. Evaluation of Certain Food Additives and Contaminants; 33rd Report of the Joint FAO/WHO Expert Committee on Food Additives; Technical Report Series 776; Geneva (Switzerland): WHO. 
1 Table I. Total arsenic concentration in raw rice samples procured. All samples

2 were from an arsenic affected area of North-24-Parganas district, West Bengal. 3

\begin{tabular}{|c|c|c|c|}
\hline Sample Cultivar (number of samples) & Type of Rice & $\begin{array}{l}\text { Mean t-As } \\
\left(\mu \mathrm{gg}^{-1}\right)\end{array}$ & $\begin{array}{c}\text { Mean i-As } \\
\left(\mu \mathrm{g} \mathrm{kg}^{-1}\right)\end{array}$ \\
\hline Khitish, Initial Evolution Trial IET-4094 (3) & Boro $^{+}$ & $272 \pm 20$ & $247 \pm 7$ \\
\hline Jaladhi-2, BAKU (3) & Boro $^{+}$ & $410 \pm 11$ & $407 \pm 8$ \\
\hline Aditya Initial Evolution Trial IET-7613 (3) & Aus $^{\ddagger}$ & $178 \pm 14$ & $165 \pm 7$ \\
\hline Biraj, CNM-539 (3) & Aus $^{\ddagger}$ & $125 \pm 12$ & $116 \pm 13$ \\
\hline Khitish, Initial Evolution Trial IET-4094 (3) & $\operatorname{Aman}^{\gamma}$ & $166 \pm 16$ & $140 \pm 9$ \\
\hline Ratna, IET-1411 (3) & $\operatorname{Aman}^{\gamma}$ & $133 \pm 14$ & $120 \pm 11$ \\
\hline Khitish, Initial Evolution Trial IET-7328 (3) & $\operatorname{Aman}^{\gamma}$ & $177 \pm 16$ & $163 \pm 5$ \\
\hline
\end{tabular}

$4+$ Boro: irrigation done by groundwater during summer time (November to June).

$5{ }^{\ddagger}$ Aus: prekharif (April to September). ${ }^{\gamma}$ Aman: irrigation done by rainwater 6 (kharif: June to December). 
Table II. Instrumental and analytical conditions for HPLC-HG-AFS.

\section{HPLC}

\begin{tabular}{|c|c|}
\hline Column & Hamilton PRP-X100 \\
\hline Guard column & Hamilton PRP-X100 \\
\hline Mobile phase & $\begin{array}{l}10 \mathrm{mM} \mathrm{k}_{2} \mathrm{HPO}_{4} / \mathrm{KH}_{2} \mathrm{PO}_{4} \text { adjusted to } \mathrm{pH} 6.0 \\
\text { (isocratic) }\end{array}$ \\
\hline Injection volume & $50 \mu \mathrm{L}$ \\
\hline Flow rate & $0.8 \mathrm{~mL} \mathrm{~min}^{-1}$ \\
\hline & HG-AFS \\
\hline Reducing agent & $1.4 \%(w / v) \mathrm{NaBH} 4$ in $0.4 \%(w / v) \mathrm{NaOH}$ \\
\hline Flow rate of reducing agent & $1.0 \mathrm{~mL} \mathrm{\textrm {min } ^ { - 1 }}$ \\
\hline $\mathrm{HCl}$ & $1.5 \mathrm{M}$ \\
\hline $\mathrm{HCl}$ flow rate & $1.5 \mathrm{~mL} \mathrm{~min}^{-1}$ \\
\hline Carrier gas & argon \\
\hline Carrier gas flow rate & $200 \mathrm{~mL} \mathrm{~min}^{-1}$ \\
\hline Hydrogen flow rate & $60 \mathrm{~mL} \mathrm{~min}^{-1}$ \\
\hline Resonance wavelength & $193.7 \mathrm{~nm}$ \\
\hline
\end{tabular}


1 Table III. Effect of the arsenic concentration (50, 250, or $\left.500 \mu \mathrm{g} \mathrm{L}^{-1}\right)$ present in 2 the cooking water on the variables under study in the cooking of rice.

\section{Absorbed Water in Cooked Rice $(\mathrm{mL})$}

50

250

500

Discarded Water $(\mathbf{m L})$
As in Cooking Water $\left(\mu \mathrm{g} \mathrm{L}^{-1}\right)$
Mean $\pm \mathrm{ES}^{\dagger}$

$\begin{array}{ll}548 \pm 15^{\mathrm{a}} \\ 50 & 583 \pm 16^{\mathrm{a}} \\ 548 \pm 15^{\mathrm{a}}\end{array}$

50

250

500

As in Cooked Rice $\left(\mu \mathbf{g ~}^{-1}\right)$

50

250

500

As in Discarded Water $\left(\mu \mathrm{g} \mathrm{L}^{-1}\right)$

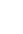

0

50

\section{(5)}

50

250

500

As Retention in Cooked Rice (\%)

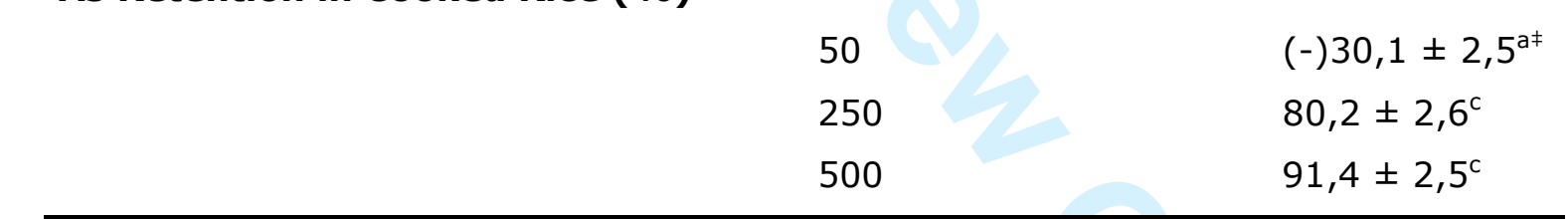

$3{ }^{7}$ Mean \pm ES: Mean value of three replicates \pm standard error. ${ }^{\ddagger}$ Values with the

4 same letters were not significantly different at $p<0.05$ for the variable studied

5 (Tukey multiple range test). 
1 Table IV. Effect of the arsenic species (arsenite, arsenate, MA, or DMA) present 2 in the cooking water on the variables under study in the cooking of rice.

\begin{tabular}{|c|c|c|}
\hline Variable & As Species & Mean $\pm \mathbf{E S}^{\dagger}$ \\
\hline \multirow[t]{4}{*}{ Absorbed Water in Cooked Rice $(\mathbf{m L})$} & Arsenite $^{*}$ & $639 \pm 17^{a \neq}$ \\
\hline & Arsenate & $496 \pm 17^{b}$ \\
\hline & MA & $562 \pm 18^{b}$ \\
\hline & DMA & $540 \pm 17^{b}$ \\
\hline \multirow[t]{4}{*}{ Discarded Water $(\mathbf{m L})$} & Arsenite & $111 \pm 17^{\mathrm{a}}$ \\
\hline & Arsenate & $254 \pm 17^{b}$ \\
\hline & MA & $188 \pm 18^{\mathrm{b}}$ \\
\hline & DMA & $210 \pm 17^{b}$ \\
\hline \multirow[t]{4}{*}{ As in Cooked Rice $\left(\mu \mathbf{g ~ k g}^{-1}\right)$} & Arsenite & $1001 \pm 25^{a}$ \\
\hline & Arsenate & $855 \pm 25^{b}$ \\
\hline & MA & $915 \pm 27^{\mathrm{ab}}$ \\
\hline & DMA & $886 \pm 25^{b}$ \\
\hline \multirow[t]{4}{*}{ As in Discarded Water $\left(\mu \mathrm{g} \mathrm{L}^{-1}\right)$} & Arsenite & $230 \pm 16^{a}$ \\
\hline & Arsenate & $298 \pm 16^{b}$ \\
\hline & MA & $308 \pm 17^{b}$ \\
\hline & DMA & $302 \pm 16^{b}$ \\
\hline
\end{tabular}

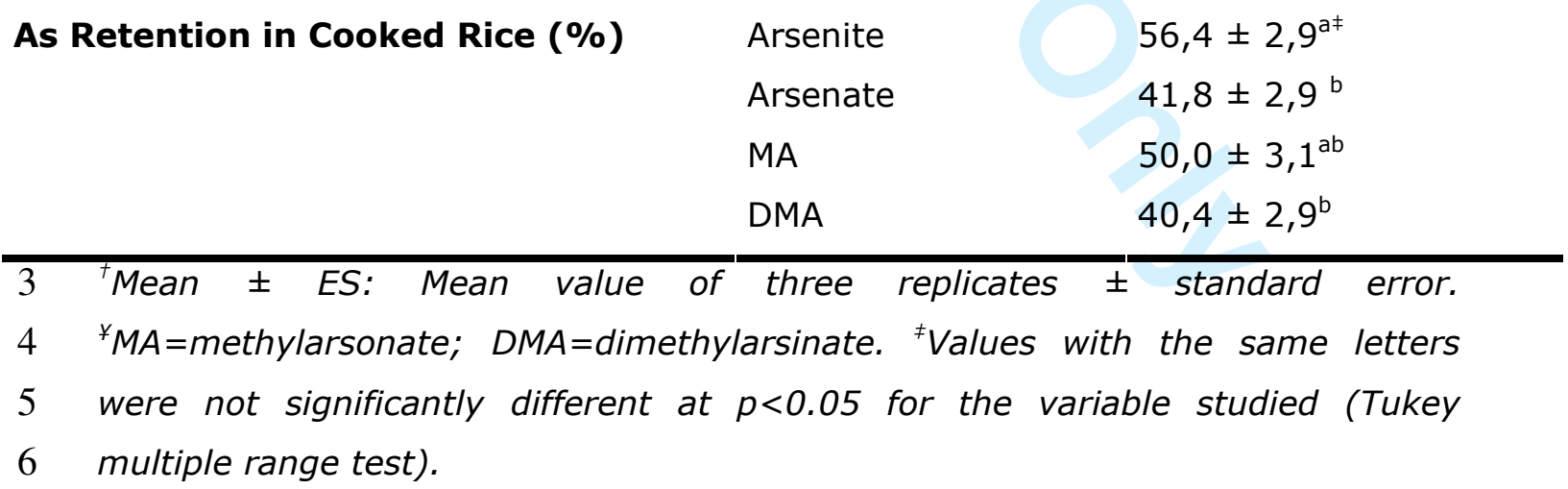


1 Table V. Content of arsenic species (arsenite, arsenate, MA, and DMA) in cooked 2 rice. In the present cooking process, water containing only one arsenic species, 3 at $250 \mu \mathrm{g} \mathrm{L}^{-1}$, and a cooking ratio of water:rice of 3:1 (750 mL water: $250 \mathrm{~g}$ rice) 4 were used.

5

\begin{tabular}{llcc}
\hline \multicolumn{1}{c}{ Initial As } & As Species & Added As (\%) & Found As (\%) \\
\hline Arsenite & Arsenite & 93.6 (rice+water) & 89.9 \\
& Arsenate & 3.9 (rice) & 10.1 \\
& MA & 0 & 0 \\
Arsenate & DMA & 2.5 (rice) & 0 \\
& Arsenite & 20.2 (rice) & 9.9 \\
& Arsenate & 77.3 (rice+water) & 90.1 \\
& MA & 0 & 0 \\
MA & DMA & 2.5 (rice) & 0 \\
& Arsenite & 20.2 (rice) & 6.9 \\
& Arsenate & 3.9 (rice) & 12.4 \\
& MA & 73.4 (water) & 80.7 \\
& DMA & 2.5 (rice) & 0 \\
DMA & Arsenite & 20.2 (rice) & 7.6 \\
& Arsenate & 3.9 (rice) & 10.7 \\
& MA & 0 & 0 \\
& DMA & 75.9 (rice+water) & 81.7
\end{tabular}

$6{ }^{+}$A total of $255.5 \mu \mathrm{g}$ of As were added to each system (187.5 $\mu \mathrm{g}$ from cooking

7 water and $68.0 \mu \mathrm{g}$ from raw rice). From this total amount 236.5, 231.9, 242.6,

8 and $234.7 \mu \mathrm{g}$ were found after cooking in the arsenite, arsenate, MA, and DMA

9 systems, respectively. 
1 Table VI. Daily dietary arsenic intake from water and cooked rice. It is assumed that each people drinks daily about $2.5 \mathrm{~L}$ of water and eats daily about $0.450 \mathrm{~kg}$ of cooked rice.

\begin{tabular}{|c|c|c|c|c|c|c|}
\hline \multicolumn{7}{|l|}{ TOTAL ARSENIC } \\
\hline $\begin{array}{c}\text { As in drinking/cooking } \\
\text { water }\left(\mu \mathrm{L} \mathrm{L}^{-1}\right)\end{array}$ & $\begin{array}{c}\text { AsIDW } \\
\left(\mu \text { As day }^{-1}\right)\end{array}$ & $\begin{array}{l}\text { AsIDW } \\
\text { (\% TAI) }\end{array}$ & $\begin{array}{l}\text { As in cooked } \\
\text { rice }\left(\mu \mathrm{g} \mathrm{kg}{ }^{-1}\right)\end{array}$ & $\begin{array}{c}\text { AsICR } \\
\left(\mu g \text { As day }^{-1}\right)\end{array}$ & $\begin{array}{c}\text { AsICR } \\
\text { (\% TAI) }\end{array}$ & $\begin{array}{c}\text { DAsI } \\
\left(\mu \mathrm{g} \mathrm{As} \mathrm{day}{ }^{1}\right)\end{array}$ \\
\hline 250 & 625 & 61.4 & 874 & 393 & 38.6 & 1018 \\
\hline 500 & 1250 & 62.8 & 1642 & 739 & 37.2 & 1989 \\
\hline \multicolumn{7}{|l|}{ INORGANIC ARSENIC } \\
\hline 50 & 125 & 54.6 & 231 & 104 & 45.4 & 229 \\
\hline 250 & 625 & 61.0 & 887 & 399 & 39.0 & 1024 \\
\hline 500 & 1250 & 62.5 & 1667 & 750 & 37.5 & 2000 \\
\hline
\end{tabular}

AsIDW=arsenic intake from drinking water; AsICR=arsenic intake from cooked rice; DAsI=Total arsenic daily intake. 
FIGURE CAPTIONS

3 Figure 1. Example of HPLC-HG-AAS chromatograms of arsenic species. (a)

4 Standard of $50 \mu \mathrm{g} \mathrm{L}^{-1}$ of arsenite, DMA, MA, and arsenate. (b) NIST SRM 1568a,

5 rice flour. (c) Raw rice. (d) Cooked rice using cooking water polluted with 6 arsenite. 

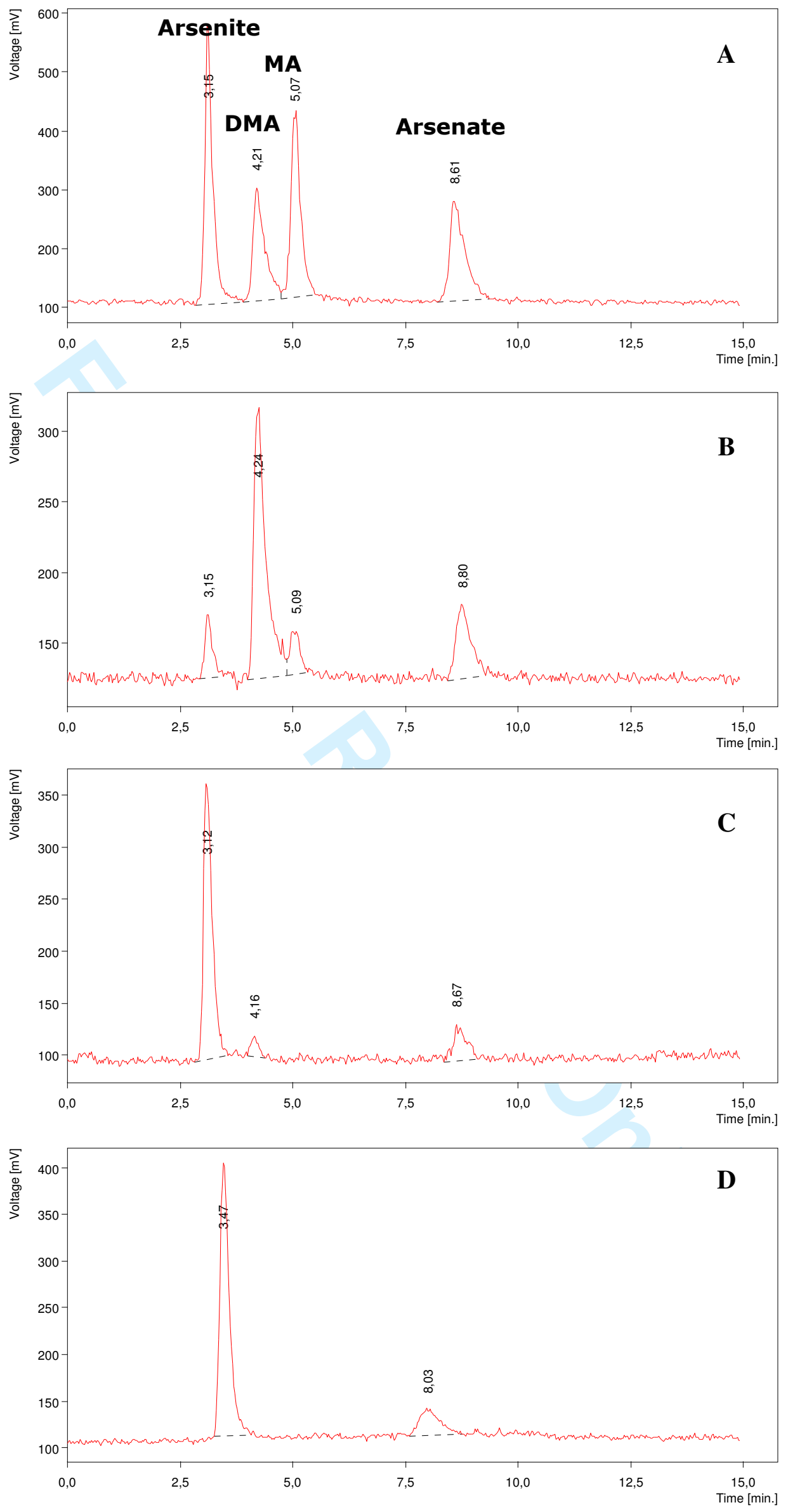